\title{
Model Hidrodinamika Pasang Surut di Perairan Pesisir Barat Kabupaten Badung, Bali
}

\author{
Made Narayana Adibhusana ${ }^{\mathrm{a} *}$, I Gede Hendrawan ${ }^{\mathrm{a}}$, I Wayan Gede Astawa Karang ${ }^{\mathrm{a}}$ \\ ${ }^{a}$ Program Studi Ilmu Kelautan, Fakultas Kelautan dan Perikanan, Universitas Udayana, Bukit Jimbaran, Bali 80361, Indonesia \\ *Penulis koresponden. Tel.: +62-822-2794-2943 \\ Alamate-mail: narayana.ade@gmail.com
}

Diterima (received) 27 Juli 2016; disetujui (accepted) 19Agustus 2016; tersedia secara online (available online) 21 Agustus 2016

\begin{abstract}
Finite Volume Coastal Ocean Model (FVCOM) is using for numerical modeling of hydrodynamic tidal water in west coast of Badung regency, Bali. The model result is validation with field observations data in the area using the equation Root Mean Square Error (RMSE). Field tidal data elevation of sea level elevation measurements were obtained by using the palm of tidal. Field data speed and direction of sea currents obtained using Lagrangian method. Excellent results obtained with RMSE values tidal elevation of sea level by $0.24 \mathrm{~m}$ dan RMSE values for sea current is $0.125 \mathrm{~m} / \mathrm{s}$. The results of model simulations show sea current patterns in the waters of the west coast of Badung regency, Bali relatively the same at the spring tide and neap tide conditions. The pattern of sea currents at high tide shows current vector that moves in toward the water of the west coast of Badung regency area from Bali Strait and the Indian Ocean. At the time of low tide sea current vector movement towards Bali Strait and the India Ocean. Sea current velocity in the eastern waters of the west coast of Badung regency (longitude of $115,05^{\circ}-115,17^{\circ}$ ) is higher than the sea current velocity in western waters area (longitude of $114,95^{\circ}-115,05^{\circ}$ ). Sea current velocity in the waters of the west coast of Badung regency on the condition of the spring tide range from 0.005 to $0.025 \mathrm{~m} / \mathrm{s}$, on the other side the sea current velocity on the neap tide conditions range from 0.005 to $0.012 \mathrm{~m} / \mathrm{s}$.
\end{abstract}

Keywords: tide; sea current; spring; neap

\begin{abstract}
Abstrak
Pemodelan numerik hidrodinamika pasang surut di kawasan perairan pesisir barat Kabupaten Badung, Bali menggunakan model Finite Volume Coastal Ocean Model (FVCOM). Verifikasi model numerik yang dibangun dalam penelitian ini dilakukan dengan membandingkan hasil simulasi dengan pengamatan lapangan di daerah tersebut menggunakan persamaan Root Mean Square Error (RMSE). Data lapangan elevasi pasang surut muka air laut diperoleh dengan melakukan pengukuran elevasi pasang surut menggunakan palem pasut. Sementara data kecepatan dan arah arus di peroleh dengan menggunakan metode Lagrangian. Hasil yang diperoleh sangat baik dengan nilai RMSE elevasi pasang surut muka air laut sebesar 0,24 m dan nilai RMSE untuk kecepatan arus $0,125 \mathrm{~m} / \mathrm{s}$. Hasil simulasi model menunjukkan pola arus di kawasan perairan pesisir barat Kabupaten Badung, Bali relatif sama pada kondisi purnama dan perbani. Pola arus pada saat pasang menunjukan vektor arus yang bergerak masuk menuju perairan pesisir barat Kabupaten Badung berasal dari perairan Selat Bali dan Samudera Hindia. Pada saat surut vektor arus bergerakan menuju perairan Selat Bali dan Samudera Hindia. Kecepatan arus pada bagian timur perairan pesisir barat Kabupaten Badung $\left(115,05^{\circ} \mathrm{BT}-115,17^{\circ} \mathrm{BT}\right)$ lebih tinggi dibandingkan dengan kecepatan arus pada bagian barat perairan $\left(114,95^{\circ} \mathrm{BT}-115,05^{\circ} \mathrm{BT}\right)$. Kecepatan arus di perairan pesisir barat Kabupaten Badung pada kondisi purnama berkisar 0,005 - 0,025 m/s, sementara pada kondisi perbani kecepatan arus di perairan pesisir barat Kabupaten Badung berkisar 0,005-0,012 m/s.
\end{abstract}

Kata Kunci: pasang surut; arus; purnama; perbani

\section{Pendahuluan}

Kawasan pantai pesisir barat Kabupaten Badung merupakan kawasan yang telah dimanfaatkan sebagai kawasan pariwisata. Kawasan ini juga tidak terlepas dari permasalahan. Salah satu permasalah yang dialami kawasan pantai pesisir barat kabupaten Badung, Bali adalah permasalah sampah. Setiap tahunnya kawasan pesisir kabupaten Badung khususnya kawasan pesisir barat yaitu pantai Jimbaran, Kelan, Kuta hingga Seminyak menerima kiriman sampah dari laut (Rohmat, 2013; www.denpostnews.com, 2014). Total sampah pada bulan
Januari 2014 mencapai \pm 1.700 ton, dengan rata-rata timbunan sampai \pm 30 ton/hari (ppebalinursa.menlh.go.id, 2015).

Sampah laut terbagi menjadi dua tipe yaitu partikel yang secara langsung dapat tenggelam di dasar laut dan partikel yang mengapung dipermukaan yang kemudian terbawa arus hingga terdeposisi di pantai (Hardesty dan Wilcox, 2011). Sumber datangnya sampah dapat diketahui dengan melakukan penelusuran pergerakan partikel sampah di laut. Pola pergerakan sampah di laut mengikuti pola pergerakan arus laut. Pola pergerakan arus laut dapat 
diketahui melalui karakteristik oseanografi di daerah tersebut, salah satunya hidrodinamika pasang surut.

Kajian hidrodinamika pasang surut di suatu wilayah perairan dapat dilakukan melalui berbagai metode diantaranya pengukuran langsung di lapangan atau melalui penginderaan jauh, cara ini cukup akurat namun memerlukan, waktu, biaya dan tenaga yang yang banyak. Cara lain yang dapat ditempuh adalah melalui aplikasi model numerik., data yang diperlukan cukup untuk keperluan validasi saja sehingga lebih efisien dari segi waktu, biaya, dan tenaga. Hasil model yang telah divalidasi dan telah menunjukkan korelasi atau kemiripan dengan kondisi sebenarnya di lapangan dapat digunakan untuk memprediksi dinamika berbagai proses yang terjadi di perairan (Ramming and Kowalik, 1980), sehingga survey lapangan yang biasanya dilakukan berbulan-bulan, hanya cukup dilakukan dalam beberapa hari saja sebagai bahan validasi lapangan model untuk prediksi.

Penelitian ini dilakukan untuk mendapatkan pola arus permukaan yang dibangkitkan oleh pasang surut pada kawasan perairan perairan pesisir barat kabupaten Badung, Bali. Penelitian mengenai pola arus permukaan di kawasan perairan pesisir barat Kabupaten Badung, Bali diperlukan sebagai bahan masukan dan informasi tambahan bagi para pengelola wilayah perairan ini karena pencemaran sampah di kawasan pantai dapat berasal dari sampah yang di bawa arus laut.

\section{Metode Penelitian}

\subsection{Lokasi Penelitian}

Studi model hidrodinamika pasang surut dilakukan pada perairan pesisir barat Kabupaten Badung, Bali dengan batas wilayah model $114,95^{\circ} \mathrm{BT}-115,17^{\circ} \mathrm{BT}$ dan $8,62^{\circ}$ $\mathrm{LS}-8,83^{\circ} \mathrm{LS}$.

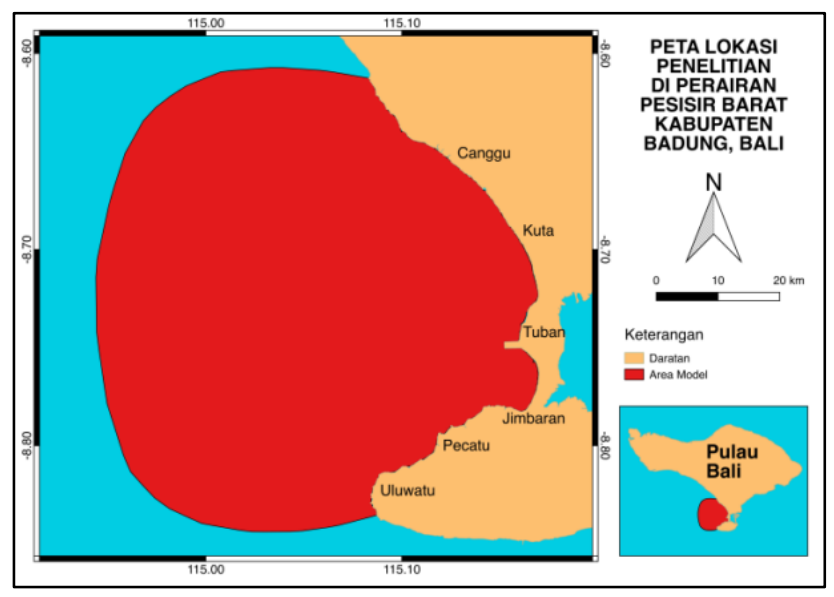

Gambar 1. Peta Lokasi Penelitian

\subsection{Persamaan Dasar Hidrodinamika}

Finite Volume Coastal Ocean Model (FVCOM) merupakan model perairan laut 3-dimensi dengan sistem grid yang tidak terstruktur (unstructured triangular grid) sehingga dapat memberikan hasil yang lebih baik untuk kondisi garis pantai yang sangat kompleks (Chen et al., 2006).
Persamaan dasar FVCOM dibangun dari persamaan momentum, kontinuitas, temperature, salinitas dan persamaan densitas (Chen et al., 2006):

$$
\begin{aligned}
& \frac{\partial u}{\partial t}+u \frac{\partial u}{\partial x}+v \frac{\partial u}{\partial y}+w \frac{\partial u}{\partial z}-f v \\
& =-\frac{1}{\rho_{o}} \frac{\partial P}{\partial x}+\frac{\partial}{\partial z}\left(K_{m} \frac{\partial u}{\partial z}\right)+F_{u} \\
& \frac{\partial v}{\partial t}+u \frac{\partial v}{\partial x}+v \frac{\partial v}{\partial y}+w \frac{\partial v}{\partial z}+f u \\
& =-\frac{1}{\rho_{o}} \frac{\partial}{\partial y}+\frac{\partial}{\partial z}\left(K_{m} \frac{\partial v}{\partial z}\right)+F_{v} \\
& \frac{\partial P}{\partial z}=-\rho g \\
& \frac{\partial u}{\partial x}+\frac{\partial v}{\partial y}+\frac{\partial w}{\partial z}=0 \\
& \frac{\partial T}{\partial t}+u \frac{\partial T}{\partial x}+v \frac{\partial T}{\partial y}+w \frac{\partial T}{\partial z}=\frac{\partial}{\partial}\left(K_{h} \frac{\partial T}{\partial z}\right)+F_{T} \\
& \frac{\partial S}{\partial t}+u \frac{\partial S}{\partial x}+v \frac{\partial S}{\partial y}+w \frac{\partial S}{\partial z}=\frac{\partial}{\partial}\left(K_{h} \frac{\partial S}{\partial z}\right)+F_{S}
\end{aligned}
$$

dimana $x, y$, dan $z$ adalah arah timur-barat, utara-selatan dan vertikal pada sistem koordinat Cartesian; $u, v$, dan $w$ adalah komponen kecepatan pada sumbu $x, y$, dan $z ; T$ adalah temperatur; $S$ adalah salinitas; $\rho$ adalah densitas; $P$ adalah tekanan; $f$ adalah parameter Coriolis; $g$ adalah percepatan gravitasi; $K_{m}$ adalah koefisien vertikal viskositas eddy; dan $K_{h}$ adalah koefisien difusi termal vertikal eddy. $F_{u}, F_{v}, F_{T}$, dan $F_{S}$ merupakan komponen momentum horizontal, termal, dan disfusi salinitas. Total kedalaman kolom perairan adalah $D=H+\zeta$, dimana $H$ adalah kedalaman dasar perairan (tergantung dari $z=0$ ) dan $\zeta$ adalah tinggi elevasi permukaan (tergantung dari $z=0)$.

\subsection{Desain Model}

Grid model dibuat dengan dengan resolusi 50 - 500 meter. Resolusi grid 50 meter digunakan pada batas tertutup (garis pantai) dan resolusi grid 500 meter digunakan pada batas terbuka. Input data batimetri diperoleh dari peta perairan Selat Bali yang diterbitkan oleh DISHIDROS TNI-AL.

Syarat batas model yang digunakan dibagi menjadi dua tipe, yaitu syarat batas terbuka dan syarat batas tertutup. Syarat batas tertutup merupakan syarat batas yang berbatasan langsung dengan daratan dan kondisi keccepatan arus pada batas tertutup selalu dianggap nol. Syarat batas terbuka merupakan wilayah titik terluar dan diberi elevasi permukaan dibatas terbuka model.

Pada batas terbuka akan digunakan input elevasi pasang surut. Input elevasi pasang surut diperoleh dari model pasang surut yang dikembangkan oleh Ocean Research Institute (ORI), Universitas Tokyo (ORI-Tide) (Matsumoto et al., 1995). Sementara untuk nilai awal yang digunakan adalah nol untuk elevasi dan juga kecepatan arus dalam domain model. Secara umum, desain model wilayah perairan pesisir barat Kabupaten Badung, Bali dapat dilihat pada Tabel 1. 
Tabel 1.

Desain model wilayah perairan pesisir barat kabupaten Badung, Bali

\begin{tabular}{|c|c|}
\hline Item & Keterangan \\
\hline Grid & $\begin{array}{l}\text { Unstructural triangular grid } \\
\text { dengan resolusi 50-500 meter }\end{array}$ \\
\hline Layer & 3 Lapisan layer \\
\hline Input & $\begin{array}{l}\text { - Elevasi pasang surut (K1, O1, } \\
\text { M2, S2) } \\
\text { - Batimetri } \\
\text { - Garis lintang } \\
\text { - Temperatur, salinitas dan } \\
\text { densitas: konstan }\end{array}$ \\
\hline Nilai Awal & $\begin{array}{l}\text { Nol untuk kecepatan arus dan } \\
\text { elevasi pasang surut pada domain } \\
\text { model }\end{array}$ \\
\hline $\begin{array}{l}\text { Syarat batas } \\
\text { terbuka }\end{array}$ & Elevasi pasang surut \\
\hline $\begin{array}{l}\text { Syarat batas } \\
\text { tertutup }\end{array}$ & Selalu dianggap nol \\
\hline Syarat stabilitas & Courant Friedrich Levy (CFL) \\
\hline $\begin{array}{l}\text { Langkah waktu } \\
\text { (time step) }\end{array}$ & 1 detik \\
\hline Waktu simulasi & 30 hari \\
\hline
\end{tabular}

\subsection{Verifikasi Hasil Model}

Verifkasi hasil model dilakukan dengan membandingkan data hasil model dengan data lapangan. Hasil model yang diverifikasi adalah elevasi pasang surut dan kecepatan arus. Data lapangan elevasi pasang surut di ambil dengan melakukan pengukuran menggunakan palem pasut pada kordinat $115,166408^{\circ} \mathrm{BT}$ dan $8,757506^{\circ} \mathrm{LS}$ selama tiga hari dari tanggal 7 Januari 2016 sampai dengan 10 Januari 2016. Data lapangan kecepatan arus diperoleh dengan melakukan pengukuaran pada tanggal 2 Maret 2016 menggunakan metode Lagrange selama enam jam di lokasi penelitian.

Hasil data lapangan kemudian dibandingkan dengan data hasil model menggunakan persamaan Root Mean Square Error (RMSE).

$R M S E=\sqrt{\frac{\sum_{i=1}^{n}\left(X_{o b s, i}-X_{\text {model }, i}\right)^{2}}{n}}$

dimana $X_{o b s}$ adalah nilai pengamatan di lapangan dan $X_{\text {model }}$ adalah nilai yang diberikan oleh model, dan $\mathrm{n}$ adalah jumlah data

\section{Hasil dan Pembahasan}

\subsection{Verifikasi Eelevasi Pasang Surut Muka Air Laut dan Kecepatan Arus}

Verifikasi elevasi pasang surut muka ari laut hasil simulasi model dengan data lapangan hasil pengukuran secara umum menunjukan pola yang sama, seperti yang ditunjukan Gambar 2. Hasil perbandingan elevasi pasang surut muka air laut hasil simulasi model dengan data lapangan dengan metode RMSE memberikan hasil 0,24 m.

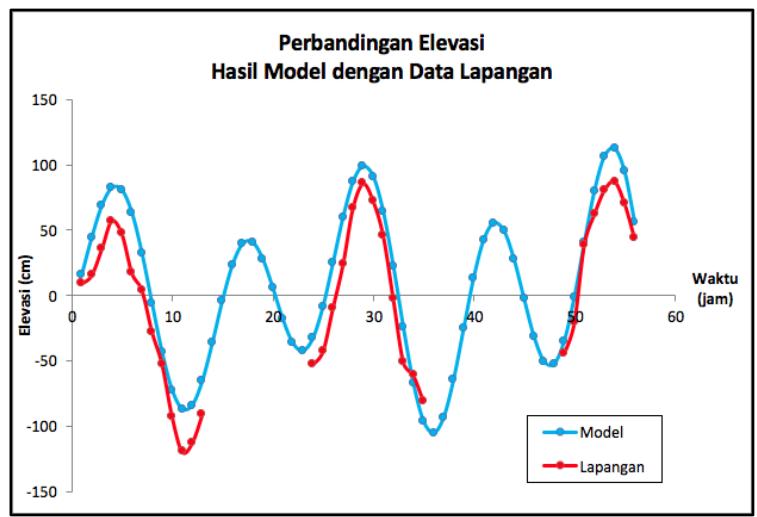

Gambar 2. Verifikasi elevasi pasang surut muka air laut hasil model dengan selevasi data lapangan.

Verifikasi arus hasil model dengan arus hasil pengukuran lapangan secara umum memiliki pola yang sama, seperti yag ditunjukkan Gambar 3. Hasil perbandingan kecepatan arus hasil model dan kecepatan arus data lapangan dengan metode RSME memberikan hasil $0,1295 \mathrm{~m} / \mathrm{s}$.

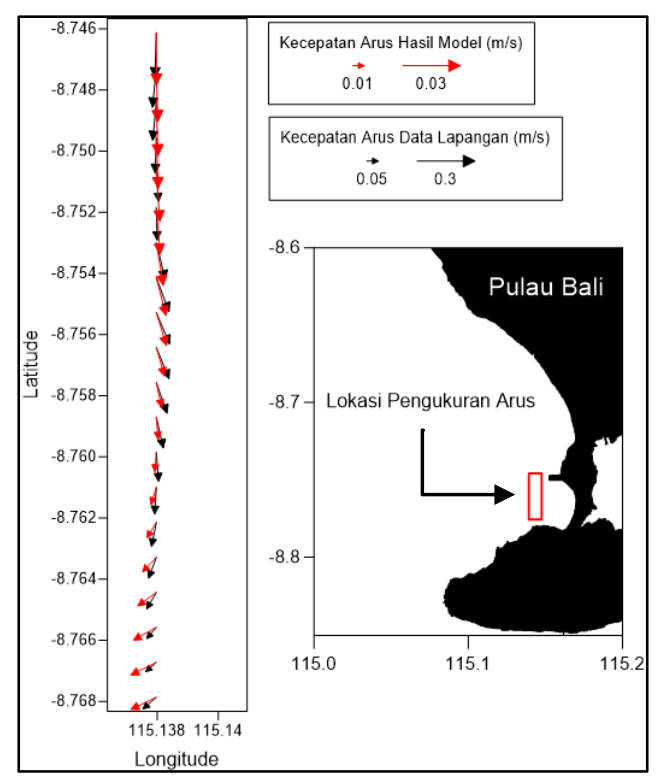

Gambar 3. Verifikasi kecepatan dan arah arus hasil model dengan arah arus data lapangan

Perbedaan hasil model dengan data lapangan disebabkan kareana input yang digunakan dalam model hanya menggunakan 4 komponen pasang surut yaitu S2, M2, K1 dan O1. Selain itu pada model juga tidak menggunakan input kecepatan angin sebagai gaya pembangkit arus.

Secara umum eleveasi pasang surut muka air laut, kecepatan dan arah arus hasil model sudah merepresentasikan keadaan elevasi dan arus di kawasan perairan pesisir barat Kabupaten Badung, sehingga model bias digunakan untuk menggambarkan kondisi perairan pesisir barat Kabupaten Badung, Bali. 


\subsection{Pola Arus Kondisi Purnama}

Pola arus kondisi purnama di kawasan perairan pesisir barat Kabupaten Badung dapat dilihat pada Gambar 4. Pada kondisi purnama saat surut menuju pasang, vektor kecepatan arus dominan bergerak dari perairan Selat Bali yaitu dari arah barat laut dan barat perairan pesisir barat Kabupaten Badung menuju ke arah timur perairan atau menuju pantai pesisir barat Kabupaten Badung. Vektor arus pada saat surut menuju pasang juga bergerak dari arah barat daya yaitu dari Samudera Hindia menuju kearah pantai pesisir barat kabupaten Badung. Kecepatan arus pada saat surut menuju pasang berbeda pada bagian barat perairan $\left(114,95^{\circ} \mathrm{BT}-115,05^{\circ} \mathrm{BT}\right)$ dengan bagian timur perairan $\left(115,05^{\circ} \mathrm{BT}-115,17^{\circ} \mathrm{BT}\right)$. Pada bagian barat perairan, kecepatan arus lebih kecil dibandingkan dengan kecepatan arus pada bagian timur perairan. Ratarata kecepatan arus pada bagian barat perairan adalah $0,005 \mathrm{~m} / \mathrm{s}$, sedangkan pada daerah timur perairan rata-rata kecepatan arus adalah $0,025 \mathrm{~m} / \mathrm{s}$.

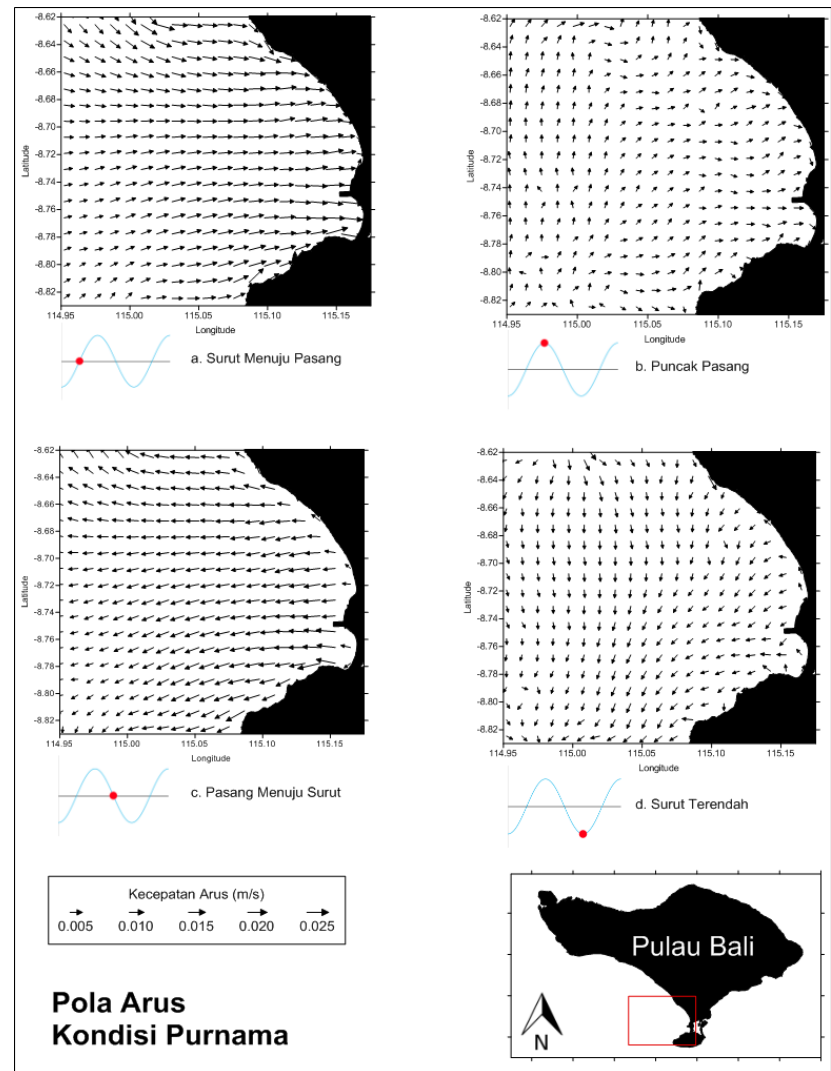

Gambar 4. Pola arus di kawasan perairan pesisir barat Kabupaten Badung, Bali pada saat kondisi purnama.

Pada saat pasang tertinggi kondisi purnama vektor kecepatan arus mengalami perubahan. Pada bagian barat perairan saat pasang tertinggi kondisi purnama, vektor kecepatan arus dominan bergerak dari arah selatan atau dari Samudera Hindia menuju ke utara perairan pesisir barat Kabupaten Badung. Sedangkan pada bagian barat perairan, vektor kecepatan arus bergerak ke arah timur perairan menuju pantai pesisir barat Kabupaten Badung. Kecepatan arus saat pasang tertinggi relatif sama pada semua bagian perairan. Rata-rata kecepatan arus pada saat pasang tertinggi adalah $0,005 \mathrm{~m} / \mathrm{s}$.

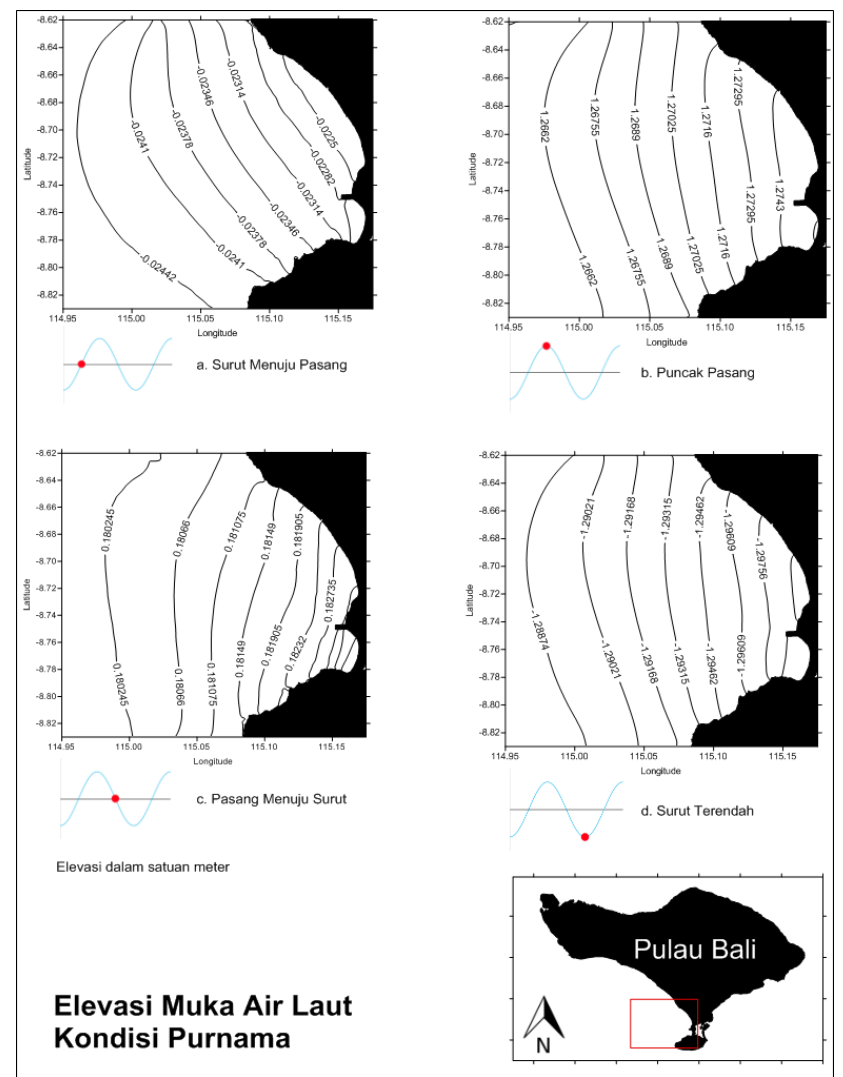

Gambar 5. Elevasi muka air laut dari rata-rata elevasi pasang surut di kawasan perairan pesisir barat Kabupaten Badung, Bali pada saat kondisi purnama

Pada saat pasang menuju surut kondisi purnama, vektor kecepatan arus bergerak ke arah perairan Selat Bali yaitu ke arah barat laut dan barat. Selain itu, vektor kecepatan arus saat pasang menuju surut kondisi purnama juga bergerak ke barat daya perairan yaitu menuju Samudera Hindia. Kecepatan arus pada perairan pesisir barat Kabupaten Badung saat pasang menuju surut berbeda pada bagian timur dengan bagian barat perairan. Kecepatan arus pada bagian timur perairan lebih besar dibandingkan dengan kecepatan arus pada bagian barat perairan. Rata-rata kecepatan arus pada bagian timur perairan pesisir barat Kabupaten Badung saat pasang menuju surut adalah $0,024 \mathrm{~m} / \mathrm{s}$. Sedangkan pada bagian barat perairan rata-rata kecepatan arus adalah $0,007 \mathrm{~m} / \mathrm{s}$.

Pada saat surut terendah kondisi purnama vektor kecepatan arus dominan bergerak kearah selatan perairan menuju Samudera Hindia. Sebagian kecil vektor kecepatan arus pada bagian timur perairan bergerak arah barat daya perairan. Kecepatan arus pada kawasan perairan pesisir barat Kabupaten Badung saat kondisi surut terendah relatif sama pada semua bagian perairan. Rata-rata kecepatan arus saat surut terendah adalah 0,006 $\mathrm{m} / \mathrm{s}$.

\subsection{Pola Arus Kondis Perbani}

Pola arus kondisi perbani di kawasan perairan pesisir barat Kabupaten Badung dapat dilihat pada Gambar 6. Pada kondisi perbani saat surut menuju pasang, vektor kecepatan arus bergerak dari dari perairan Selat Bali yaitu 
dari arah barat daya dan barat menuju pantai pesisir barat Kabupaten Badung. Selain itu vektor kecepatan arus juga bergerak dari Samudera Hindia atau dari arah barat laut perairan menuju pantai pesisir barat Kabupaten Badung. Kecepatan arus di kawasan perairan pesisir barat Kabupaten Badung saat surut menuju pasang kondisi perbani tidak terlalu berbeda antara bagian timur dengan bagian barat perairan. Pada bagian timur perairan, ratarata kecepatan arus adalah $0,012 \mathrm{~m} / \mathrm{s}$ dan pada bagian timu perairan rata-rata kecepatan arus adalah $0,006 \mathrm{~m} / \mathrm{s}$.

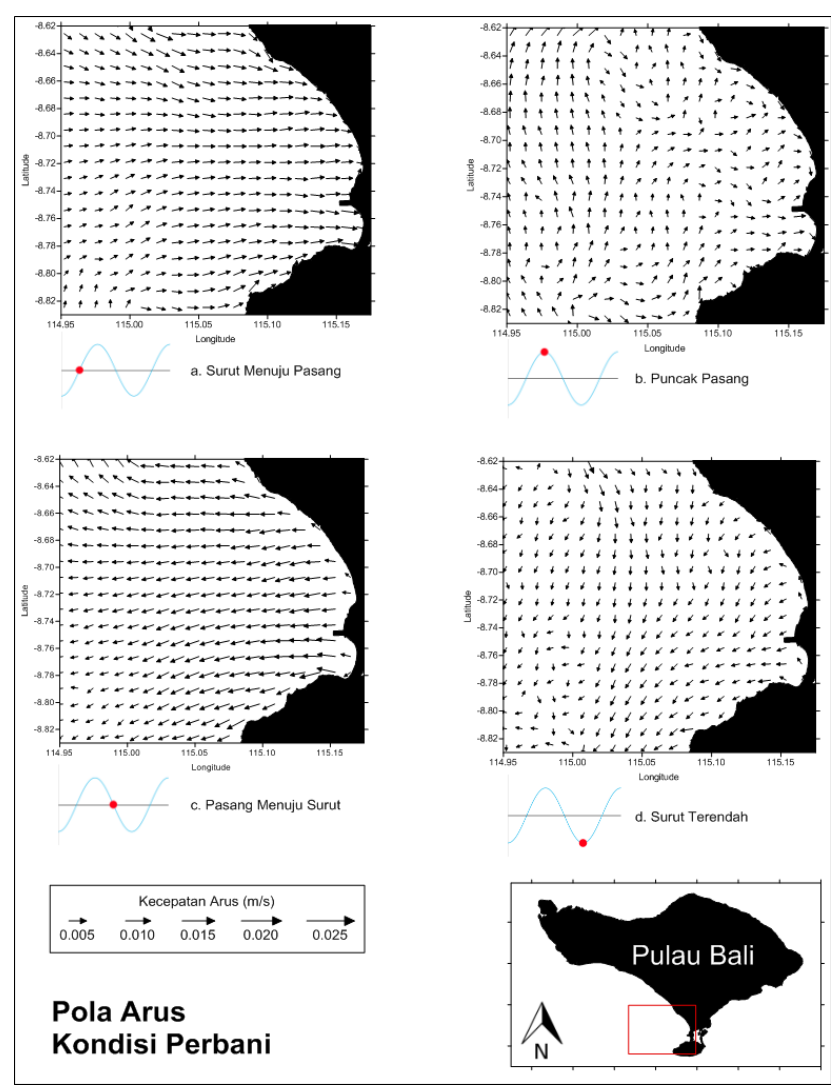

Gambar 6. Pola arus di kawasan perairan pesisir barat Kabupaten Badung, Bali pada saat kondisi perbani

Pada saat kondisi pasang tertinggi vektor kecepatan arus pada bagian barat perairan berbeda dengan bagian timur perairan. Pada bagian barat perairan, vektor arus bergerak dari selatan perairan menuju utara perairan. Pada bagian barat peraian, vektor arus bergerak ke arah timur menuju pantai pesisir barat Kabupaten Badung. Kecepatan arus saat pasang tertinggi relatif sama pada semua bagian perairan. Rata-rata kecepatan arus pada kawasan perairan pesisir barat kabupaten badung saat pasang tertinggi adalah $0,005 \mathrm{~m} / \mathrm{s}$.

Pada pasang menuju surut kondisi perbani, arah vektor kecepatan arus terbagi menjadi tiga arah. Vektor kecepatan arus bergerak ke arah barat laut dan barat perairan menuju Selat Bali. Selain itu vektor kecepatan arus juga bergerak ke arah barat daya menuju Samudera Hindia. Kecepatan arus pada bagian barat perairan berbedan dengan kecepatan arus pada bagian timur perairan. Kecepatan arus pada bagian barat perairan lebih besar dibandingkan dengan kecepatan arus pada bagian timur perairan. Pada bagian timur perairan rata-rata kecepatan arus adalah $0,014 \mathrm{~m} / \mathrm{s}$. Sedangkan pada bagian barat perairan rata-rata kecepatan arus adalah $0,007 \mathrm{~m} / \mathrm{s}$.

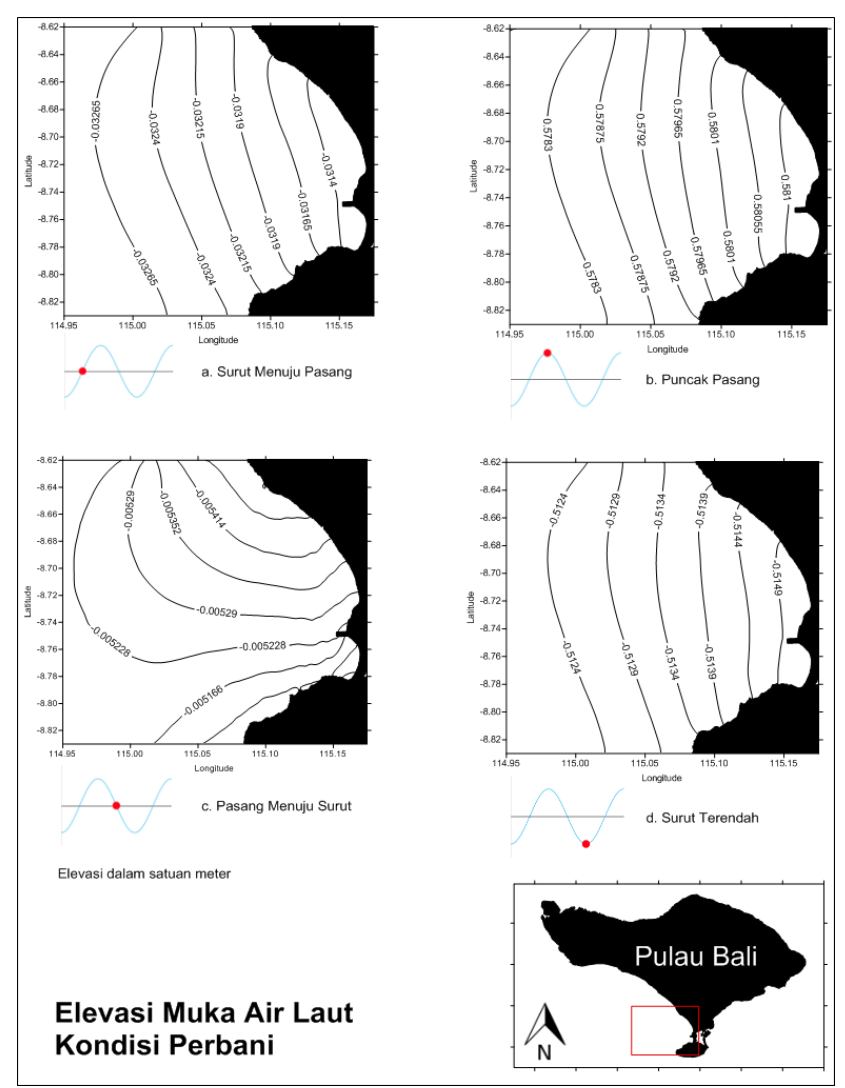

Gambar 7. Elevasi muka air laut dari rata-rata elevasi pasang surut di kawasan perairan pesisir barat Kabupaten Badung, Bali pada saat kondisi perbani

Pada saat surut terendah vektor kecepatan arus dominan bergerak kearah selatan menuju Samudera Hindia. Kecepatan arus saat surut terendah pada semua bagian perairan relatif sama. Rata-rata kecepatan arus saat kondisi surut terendah adalah $0,006 \mathrm{~m} / \mathrm{s}$.

Dari hasil simulasi tersebut terlihat bahwa pola arus di kawasan perairan pesisir barat Kabupaten Badung pada saat kondisi purnama dan kondisi perbani relatif sama. Pada saat pasang vektor arus bergerak memasuki kawasan perairan pesisir barat Kabupaten Badung menuju pantai pesisir barat Kabupaten Badung. Sedangkan pada saat surut vektor kecepatan arus bergerak meninggalkan kawasan perairan pesisir barat Kabupaten Badung menuju perairan Selat Bali dan Samudera Hindia. Rata-rata kecepatan arus pada saat kondisi purnama berkisar 0,005 $\mathrm{m} / \mathrm{s}$ sampai dengan $0,025 \mathrm{~m} / \mathrm{s}$. Hasil kecepatan arus hasil model ini serupa dengan hasil model pada penelitian yang dilakaukan oleh Hanif (2013). Kecepatan arus yang relatif kecil ini disebabkan karena kawasan perairan pesisir barat Kabupaten Badung merupakan perairan terbuka.

Elevasi muka air laut tidak terlalu mempengaruhi arus di kawasan perairan peisisr barat Kabupaten Badung. Hasil ini juga serupa dengan hasil penelitian yang dilakukan oleh Hanif (2013). Pada penelitian yang dilakukan oleh Hanif (2013) elevasi muka air laut bukan merupakan faktor dominan penggerak arus di perairan pesisir barat Kabupaten Badung. Seperti yang terlihat pada Gambar 5 dan Gambar 7, elevasi muka air laut pada 
masing masing kondisi relatif sama pada semua bagian perairan.

\section{Simpulan}

Pola arus di kawasan perairan pesisir barat Kabupaten Badung, Bali relatif sama pada kondisi purnama dan kondisi perbani. Pada saat pasang arus bergerak memasuki wilayah perairan menuju pantai pesisir barat Kabupaten Badung, Bali. Pada saat surut arus bergerak meninggalkan perairan menuju ke peairan Selat Bali dan Samudera Hindia. Arus yang masuk menuju perairan pesisir barat Kabupaten Badung berasal dari perairan Selat Bali dan Samudera Hindia. Begitu juga dengan arus yang meninggalkan perairan pesisir barat Kabupaten Badung menuju perairan Selat Bali dan Samudera Hindia.

Kecepatan arus pada bagian timur perairan lebih besar dibandingkan dnegan kecepatan arus pada bagian barat perairan. Kecepatan arus pada kondisi purnama berkisar $0,005-0,025 \mathrm{~m} / \mathrm{s}$ dan kecepatan arus pada kondisi perbani berkisar $0,005-0,012 \mathrm{~m} / \mathrm{s}$. Dari hasil simulasi juga diperoleh bahwa pasang surut tidak terlalu mempengahuri arus di perairan pesisir barat Kabupaten Badung, Bali.

\section{Ucapan Terimakasih}

Dalam pelaksanaa penelitian ini penulis banyak mendapatkan bantuan baik dari perorangan ataupun instansi/lembaga. Oleh karena itu, pada kesempatan ini penulis ingin menyampaikan ucapan terimakasi yang sebesar-besarnya kepada kepala dan staf Laboratorium Komputasi, serta teman-teman mahasiswa Fakultas
Kelautan dan Perikanan Universitas Udayana atas bantuannya selama penelitian.

\section{Daftar Pustaka}

Chen, C., R. C. Beardsley., G. Cowles. (2006). An Unstructured Grid, Finite-Volume Coastal Ocean Model (FVCOM) user manual. Diakses tanggal 1 September 2015, dari ftp://ocsftp.ncd.noaa.gov/Schmalz/SFBOFS-Project/fvcom/ FVCOM_manual.pdf).

Denpasar Post. (2014). Pantai Kuta Mulai Kotor Lagi. Diakses tanggal 3 Januari 2016, dari www.denpostnews.com/ 2014/12/12/pantai-kuta-mulai-kotor-lagi/

Hanif Diastomo. (2013). Pemodelan Gerak Sampah Laut Terapung (Marine Debris) di Selat Bali. Tugas Akhir. Bandung: Program Studi Oseanografi, Institut Teknologi Bandung.

Hardesty, BD and C Wilcox. (2011). Understanding the types, sources and at-sea distribution of marine debris in Australian waters. Australia:CSIRO Ecosystem Sciences,

Pusat Pengendalian Pembangunan Ekoregion Bali dan Nusa Tenggara. (2015). Pencemaran Sampah Kiriman di Pantai Kuta dan Sekitarnya. Diakses tanggal 1 November 2015 , dari www.ppebalinusra.menlh.go.id/pencemaran-sampahkiriman-di-pantai-kuta-dan-sekitarnya.htm

Ramming, H.G., Z. Kowalik. (1980). Numerical modelling of marine hydrodynamics: Applications to dynamics physical processes. Amsterdam (NL); Elsevier publishing for Oceanography Series 26.

Rohmat. (2013). Sampah Menggunung di Pantai Kuta Bali. Diakses tanggal 3 Januari 2016, dari www.daerah.sindonews.com/read/821057/27/sampahmenggunung-di-pantai-kuta-bali-1388074126.

(C) 2016 by the authors; licensee Udayana University, Indonesia. This article is an open access article distributed under the terms and conditions of the Creative Commons Attribution license (http://creativecommons.org/licenses/by/3.0/). 